\title{
Interplay between sensation seeking and risky alcohol drinking in Mexican adolescents: An structural modeling equation approach.
}

Relación entre la búsqueda de sensaciones y el riesgo de consumo de alcohol en adolescentes Mexicanos: Un enfoque de ecuaciones estructurales.

Jorge Palacios ${ }^{1 *}$

\begin{abstract}
Alcohol drinking represents one of the most important public health problems in adolescents. One axis of analysis of the correlates that affect alcohol consumption in adolescents is personality traits. In particular, sensation seeking maintains a consistent relationship with consumer behaviors. The objective of this research was tested in a structural equation model to show the structural effect of sensation seeking on risky alcohol drinking. The sensation seeking inventory (Palacios, 2015a) was used and alcohol drinking was measured with a survey of a sample of 550 Mexico City youth between 14 and $23(M=16.88 ; S D=1.3)$ years old The results indicated the factorial validity of alcohol drinking in this sample. The structural equation modeling analyses suggested sensation seeking is a significant predictor for alcohol drinking behavior. The discussion analyzes the influence of sensation seeking on alcohol drinking and suggests implications for interventions.

\section{Resumen}

El consumo de alcohol es uno de los problemas entre los jóvenes. Un rasgo de personalidad que estudia su efecto sobre el consumo de alcohol es la búsqueda de sensaciones. El objetivo de esta investigación fue probar en un modelo de ecuaciones estructurales, la validez factorial del consumo de alcohol, a partir de la búsqueda de sensaciones. Se administró el inventario de búsqueda de sensaciones (Palacios, 2015a) y se midió el consumo de alcohol con un cuestionario en una muestra formada por 550 jóvenes entre 14 y 23 años de edad, en la Ciudad de México. Los resultados indicaron la validez factorial del consumo de alcohol en esta muestra. El análisis de ecuaciones estructurales sugirió que la búsqueda de sensaciones es un predictor del comportamiento de consumo de alcohol. La discusión analiza la influencia de la búsqueda de sensaciones en el consumo de alcohol y se sugieren implicaciones de intervención.
\end{abstract}

\section{Keywords}

sensation seeking; structural equation modeling; risky alcohol drinking; youth

Palabras Clave

búsqueda de sensaciones; ecuaciones estructurales; riesgo del consumo de alcohol; jóvenes

${ }^{1}$ Universidad del Valle de México, Querétaro - Centro de Investigación e Innovación Biopsicosocial, AC.

*Corresponding author: jorge.palaciosd@uvmnet.edu

Manuscript received 22-12-2017; revised 06-03-2018; accepted 17-04-2018.

\section{Introduction}

Alcohol drinking represents one of the most important public health problems, especially for adolescents who begin drinking at a younger age, which carries a greater risk for developing an addiction and has serious physiological, psychological and social consequences (Gómez Fraguela, Luengo Martín, Romero Triñanes, Villar Torres, \& Sobral Fernández, 2006). These include hepatic cirrhosis, motor vehicle accident injuries, and alcohol dependence with a high incidence of chronic conditions that lead to premature death (Medina-Mora, Natera, \& Borges, 2002; Medina Mora et al., 2002). It was found that in Mexico's adolescent population, $42.9 \%$ had consumed alcohol, including $46 \%$ of men and $39.7 \%$ of women. In the last year, the prevalence of consumption was $30 \%$ (31.8\% men and $28.1 \%$ women) and $4.1 \%$ of adolescents were found to suffer from alcohol dependency $(6.2 \%$ men and 
2\% women) (Encuesta Nacional de Adicciones, 2011).

Several theoretical models have been proposed to explain the multiple factors that influence alcohol consumption (Becoña, 2005; Hawkins, Catalano, \& Miller, 1992; Jessor, 1991, 1998; Kandel, 2002; Palacios, 2011, 2015b). Among the theoretical models around alcohol drinking, a central aspect is the effect that the individual variables have on this behavior, highlighting factors that increase or decrease adolescent vulnerability to alcohol consumption. These factors include motives for consuming alcohol (Cooper, 1994; Palacios, 2012), personal well-being (Palacios \& Cañas, 2010), depression (Grant, Stewart, O'Connor, Blackwell, \& Conrod, 2007) and low self-efficacy (Bandura, 1999; Palacios \& Bustos, 2012).

Within the individual factors, one axis of analysis of the correlates that affect alcohol consumption in adolescents is personality traits. Different approaches have been used to explore the structure of personality through different cultures (Church, 2001; McCrae, 2001). While these approaches give different predictions of the behaviors that individuals can perform, they coincide in origin with either of the two most-used personality models (Palacios \& Martínez, 2017), namely 1) the five-factor personality mode (Goldberg, 1990) or 2) sensation seeking (Zuckerman, 1994). Research has documented that sensation seeking maintains a consistent relationship with consumer behaviors (Horvath \& Zuckerman, 1993; Merino-Soto \& Salas-Blas, 2018). Sensation seeking is a personality trait that is defined as the need to experience varied and complex sensations and the desire to take physical and social risks based on the desire to obtain those experiences. This concept is considered multifaceted, with different components such as emotionadventure-, and experience-seeking, disinhibition and susceptibility to boredom (Zuckerman, 1994).

A seeking concept refers to a trait that is actively expressed and the sensory effect of the external stimulation that affects the individual. The latter is very important to define its value as the primary reinforcement; that is, the external stimulus that is sought to maximize sensations. The person who is a sensation seeker is characterized by unusual actions, which for others would be dangerous and risky (Zuckerman, 1979, 1994; Zuckerman \& Kuhlman, 2000).

Sensation seeking has different models depending on the theoretical proposal from which it is based. in this respect Zuckerman $(1979,1994,2007)$ describes sensation seeking as the individual need to seek and maintain an optimal level of activation, as well as as a need for new and complex stimuli. Arnett (1994), sensation seeking is based on the dimensions of novelty and intensity. On the other hand,Roth, Hammelstein, and Brähler (2007) base their conception of sensation seeking as a need for stimulation. The evidence found shows that in trying to understand how sensation seeking is structured and eval- uated, theoretical differences emerge depending on the position from which the construct is based. Zuckerman (1994, 2007) emphasizes the biological basis of sensation seeking; Arnett (1994) emphasizes socialization as the basis for the sensations seeking; and Roth et al. (2007) conceive of sensation seeking as a need for stimulation. Recently, several studies (Chen et al., 2013; Merino-Soto \& Salas-Blas, 2018; Saletti, Chang, Pérez-Aranibar, \& Campos, 2017; Stephenson, Hoyle, Palmgreen, \& Slater, 2003; Stephenson, Velez, Chalela, Ramirez, \& Hoyle, 2007) have focused on making modifications to reduce the size of the measurement construct while maintaining stability in their psychometric properties. From the perspective of this article, sensation seeking is a personality trait with a bio-behavioral basis (Palacios, 2015a; Roberti, 2004; Zuckerman, 1994, 2007) because sensation seeking has been shown to be part of specific behavioral patterns (Palacios, Sánchez, \& Andrade, 2010). Additionally, sensation seekers choose various risky activities, including use of addictive substances (Breivik, Sand, \& Sookermany, 2017; Cooper, Wood, Orcutt, \& Albino, 2003).

Regarding the incidence of sensation seeking with the consumption of addictive substances, the results of several studies (Crawford, Pentz, Chou, Li, \& Dwyer, 2003; Hansen \& Breivik, 2001; Perkins, Gerlach, Broge, Grobe, \& Wilson, 2000) indicate that sensation seeking is a predictor of the consumption of addictive substances (alcohol, tobacco and drugs), where consumers of addictive substances score higher in sensation seeking than non-consumers (Zuckerman \& Kuhlman, 2000).

Newcomb and Bentler (1989) found that sensation seeking was significantly and positively related to the consumption of drugs, tobacco and alcohol. Alcohol consumption correlated with all subscales of sensation seeking in men and women, with the exception of the experience seeking dimension, which was not related to alcohol consumption for men. The authors conclude that sensation seeking has an effect on alcohol consumption and a specific influence on the increase in drug consumption.

A variety of studies(Hittner \& Swickert, 2006; Legrand, Kaltenbach, Joly, et al., 2007; Yanovitzky, 2006; Zuckerman, 1994, 2007) argue that high levels of sensation seeking correlate positively with alcohol consumption and recently (Smorti \& Guarnieri, 2013) positive correlations have been found between the intensity scale and alcohol consumption, as well as between the novelty scale and the amount of alcohol consumed. Research in Latin America (González-Iglesias, Gómez-Fraguela, Gras, \& Planes, 2014; Palacios \& Cañas, 2010; Romero Saletti, Olivo Chang, Pérez-Aranibar, \& Otiniano Campos, 2017; Schmidt, Molina, \& Raimundi, 2017) has found that sensation seeking scores tend to be greater among those who consume alcohol, which confirms the importance of the 
search for sensations in explaining alcohol consumption in young people.

The evidence presented so far suggests that the causes of alcohol drinking are linked to personal factors and that alcohol consumption is influenced by individual need for stimulation, as expressed through the personality trait named sensation seeking (Cooper, Agocha, \& Sheldon, 2000; Palacios, 2015a; Zuckerman, 1994, 2007). The research found emphasizes the relationship between sensation seeking and addictive behaviors, as well as their influence on the presence of these behaviors.

In addition to this, the study of sensation seeking with a new measuring instrument offers empirical support for this construct, since sensation seeking as a personality trait allows us to define to what extent an individual has this trait and the characteristic form in which they respond to certain situations. At the same time, it contributes evidence of the effect that this trait has on alcohol consumption, based on the few studies from Mexico that investigate the effect of sensation seeking on alcohol consumption in adolescents.

Therefore, the objective of this research was to use a structural equation model to test the structural effect of sensation seeking on risky alcohol drinking in a sample of Mexican adolescents.

\section{Method}

\subsection{Sample}

A non-probabilistic sample was selected. The sample consisted of students from two public high school in southern Mexico City, 550 young people of whom 260 were male and 290 female, with an age range between 14 and 23 years $(M=16.88 ; S D=1.3)$. Their participation was voluntary and they were guaranteed anonymity in their responses. A causal and cross-sectional experimental design was used to identify the effect of sensation seeking in adolescent alcohol consumption.

\subsection{Measures}

\subsubsection{Alcohol drinking}

Alcohol consumption was evaluated by four questions on the age of onset of alcohol consumption, frequency of alcohol use in the last month (from never to daily), the quantity of alcohol consumed per event (number of drinks consumed per occasion), and the incidence of heavy alcohol drinking ( 5 or more glasses per event) (from never to daily) and number of drinks they think they need to get drunk (number of drink glasses per event). Higher scores indicate higher drinking quantity (Villatoro et al., 2001). The measurement made has been proven in several studies using Mexican samples (Medina-Mora et al., 2002; Medina Mora et al., 2002; Palacios, Bravo, \& Andrade, 2007).

\subsubsection{Sensation Seeking}

The Sensation Seeking Mexican Inventory (Palacios, 2015a), was estimated using a 59 item Likert Scale, with each of the ítems having four possible responses (never to always) with eight subscales (pleasure seeking, risk seeking, intense emotion seeking, novelty seeking, thrill and adventure seeking, disinhibition, unusual seeking and boredom susceptibility) relative to a preference for sensation seeking. The scale has construct, predictive and criterion validity, as well as a coefficient of reliability of internal consistency (Cronbach's Alpha) of .88 (IC95\% =.86-.89) in Mexican samples.

\subsubsection{Procedure}

The application of the instrument to adolescents was done in a group settingin each school. The participants were provided wth a brief description of the study (about activities carried out by young people), including the following written instructions: "This questionnaire is entirely voluntary. All your responses will be kept confidential and your personal identity will remain anonymous. No identifying information is requested on this survey, nor will any such information be added later to this survey. If any of the questions make you uncomfortable, feel free not to answer them. You are free to withdraw from this study at any time for any reason. This questionnaire should take about 25 minutes to complete. Thank you for your participation." At the end of the application, each participant was given a list of telephone numbers of psychological support centers.

\subsubsection{Data Analysis}

Data analyses were performed considering descriptive statistics for alcohol drinking. Structural equation modeling (SEM) was use to evaluate the effect of sensation seeking in alcohol consumption. The test of the model was carried out by performing a series of relational and sequence analyses. Finally, the reliability of the internal consistency index (Cronbach's alpha coefficient) was calculated for the alcohol consumption indicators.

\subsubsection{Ethical considerations}

All participants were informed that the information was anonymous, and the confidentiality of the data provided was guaranteed. Participants and school authorities gave informed consent. The research protocol was established according to the Regulation of the General Health Law, in its section on human subjects research (Salud, 2011).

\section{Results}

The results show that $79.3 \%$ of the adolescents drink alcohol, starting at $13.65(S D=2.0)$ years, $42.3 \%$ ath a frequency of once a month or less, followed by $30 \%$ two or three times a week. The range of drinks consumed varies between one and more than 10 , the modal amount 
of drinks consumed per instance of consumption is between 1 and 2, constituting $23.8 \%$ of the sample, while $19.6 \%$ reported drinking between $3-4$ glasses. $40.6 \%$ reported an excessive consumption of alcohol within the past month, defined as 5 glasses or more in a single instance. In addition, students report that the number of glasses they consider needing to be drunk is on average $6.94(S D=3.4)$.

In order to obtain the metric equivalence of the indicators of alcohol consumption (frequency, quantity, age of onset, excessive consumption and quantity with which they become drunk), each one was transformed into standardized scores to obtain their normal distribution and thus be able to aggregate them in a global indicator of alcohol consumption.

Pearson correlations were performed between the indicators of alcohol consumption in order to calculate the degree of association between each one of them. Table 1 shows positive and significant correlations in the indicators of alcohol consumption. The age of onset correlates with all the indicators of alcohol consumption, the frequency of consumption shows the highest levels of asociation with excessive alcohol consumption and quantity of consumption, and in turn the excessive consumption of alcohol has the high levels of correlation with the quantity of consumption. The quantity of alcohol with which they get drunk manifests the highest correlation with the quantity of alcohol they consume, followed by frequency and excessive consumption.

A confirmatory factorial analysis (CFA) was performed to establish the factorial validity of the measure of alcohol consumption in this sample. The analysis performed with the AFC in adolescent alcohol users was shown to fit the data, providing factorial validity to the measure. The indicators of goodness of absolute fit $\left[\chi^{2}(3, N=550)=11.61, p<.001 ; \mathrm{RMSEA}=.07\right.$; $\mathrm{RMR}=.01]$; incremental adjustment (TLI $=.98 ; \mathrm{RFI}=$ $.97 ; \mathrm{IFI}=.99, \mathrm{CFI}=.99 ; \mathrm{GFI}=.99 ; \mathrm{AGFI}=.95)$ and parsimony adjustment $(\mathrm{NFI}=.99)$ showed aceptable values (Ruiz, Pardo, \& San Martín, 2010).

The reliability of the internal consistency index (Cronbach's alpha coefficient) was calculated for the alcohol consumption indicators, obtaining an index of .87 $(\mathrm{IC} 95 \%=.85-.89)$. The results suggest satisfactory levels of reliability, indicating a homogeneity in the indicators that make up the measure of alcohol drinking.

The mean score, standard deviation and range for each facet of sensation seeking are presented in Table 2. The values are near the theoretical mean, meaning there are no problems with the effect of floor or ceiling in the answers. Standard deviation is relatively consistent across the factors. The facet that has the highest score is novelty sensation. The second highest score is from intense emotion seeking and the facets of risk seeking and unusual seeking, are the facets that receive the lowest scores.

A structural equation modeling (SEM) analysis was conducted to estimate the structural association (predictive validity) between sensation seeeking and alcohol drinking. The proposed model was structurally consistent with the data. Structural equation model demostrated the direct effect of sensation seeking (structural coefficient $=0.51$ ) on alcohol drinking. The results showed that a higher sensation seeking score wa positively associated with alcohol drinking (Figure 1). The model presents a multiple coefficient of determination $R^{2}$ in the estimation of alcohol consumption of 0.20 . That is, for this model, sensation seeking explains $20 \%$ of the variability in alcohol consumption among this sample of Mexican youth.

The indicators of goodness of absolute fit $\left[\chi^{2}(61, N=\right.$ $550)=247.61, p<.001 ; \operatorname{RAMSEA}=.07 ; p-$ Close $=0.00]$; incremental adjustment $(\mathrm{TLI}=.98 ; \mathrm{RFI}=.97 ; \mathrm{IFI}=.98$, $\mathrm{CFI}=.98)$ and parsimony adjustment $(\mathrm{NFI}=.98)$ showed aceptable values. The postulated theoretical model and its relationships are supported by the data with an adequate adjustment.

\section{Discussion}

The factorial assessment of alcohol consumption obtained in this study shows how to measure the latent factors in alcohol drinking (Becoña, 2005; Horvath \& Zuckerman, 1993; Jessor, 1998; Palacios, 2015b). The evidence of the psychometric properties of validity and reliability shows a conceptual congruence between the behaviors to measure the risk in alcohol consumption by including several behaviors for its measurement, reaffirming the factorial validity of the items as they have been evaluated in this sample of Mexican youth.

Structural equation modeling demonstrated the direct effect of sensation seeking on alcohol drinking in this sample of Mexican youth. These results are theoretically (Hittner \& Swickert, 2006; Palacios, 2015a; Roberti, 2004; Zuckerman, 1994) and empirically supported (González-Iglesias et al., 2014; Horvath \& Zuckerman, 1993; Zuckerman, 2007; Zuckerman \& Kuhlman, 2000). Additionally, the effects are similar to what is reported in several studies (Legrand et al., 2007; Palacios \& Cañas, 2010; Romero Saletti et al., 2017; Yanovitzky, 2006).

The use of CFA involved a prior theory (Hittner \& Swickert, 2006; Palacios, 2015a; Roberti, 2004; Zuckerman, 1994, 2007) for its empirical estimation to verify if the measurement model coincided with the gathered information. In addition, it involved a problem to be solved and a hypothesis that could be verified. The findings obtained in the evaluated model allow us to maintain the hypothesis that alcohol consumption will be presented if the individuals tend to increase their sensation seeking by means of the amount of stimulation that they experience. 
Table 1

Correlations of the alcohol consumption

$\begin{array}{lllll}\begin{array}{l}\text { Age of } \\ \text { onset }\end{array} & \text { Frequency } & \begin{array}{l}\text { Excessive } \\ \text { consump- } \\ \text { tion }\end{array} & \text { Quantity } & \begin{array}{l}\text { Get } \\ \text { drunk }\end{array} \\ & & & \end{array}$

Age of onset

$\begin{array}{llll}.599^{* *} & .420^{* *} & .542^{* *} & .472^{* *} \\ - & .765^{* *} & .649^{* *} & .505^{* *} \\ & - & .732^{* *} & .505^{* *} \\ & - & .637^{* *} \\ & & & \end{array}$

Excessive consumption

$-\quad .599$

Quantity

Get drunk

\section{Table 2}

Descriptive statistics of sensation seeking inventory

\begin{tabular}{lllll}
\hline & $\boldsymbol{M}$ & $\boldsymbol{S D}$ & Mín & Max. \\
Pleasure seeking & & & & 3.9 \\
Risk seeking & 2.33 & 0.65 & 1 & 4 \\
Intense emotion seeking & 2.18 & 0.67 & 1 & 4 \\
Novelty seeking & 2.99 & 0.72 & 1 & 4 \\
Thrill and adventure seeking & 3.02 & 0.60 & 1 & 4 \\
Disinhibition & 2.71 & 0.65 & 1 & 4 \\
Unusual seeking & 2.49 & 0.80 & 1 & 4 \\
Boredom susceptibility & 2.27 & 0.60 & 1 & 4 \\
\hline
\end{tabular}

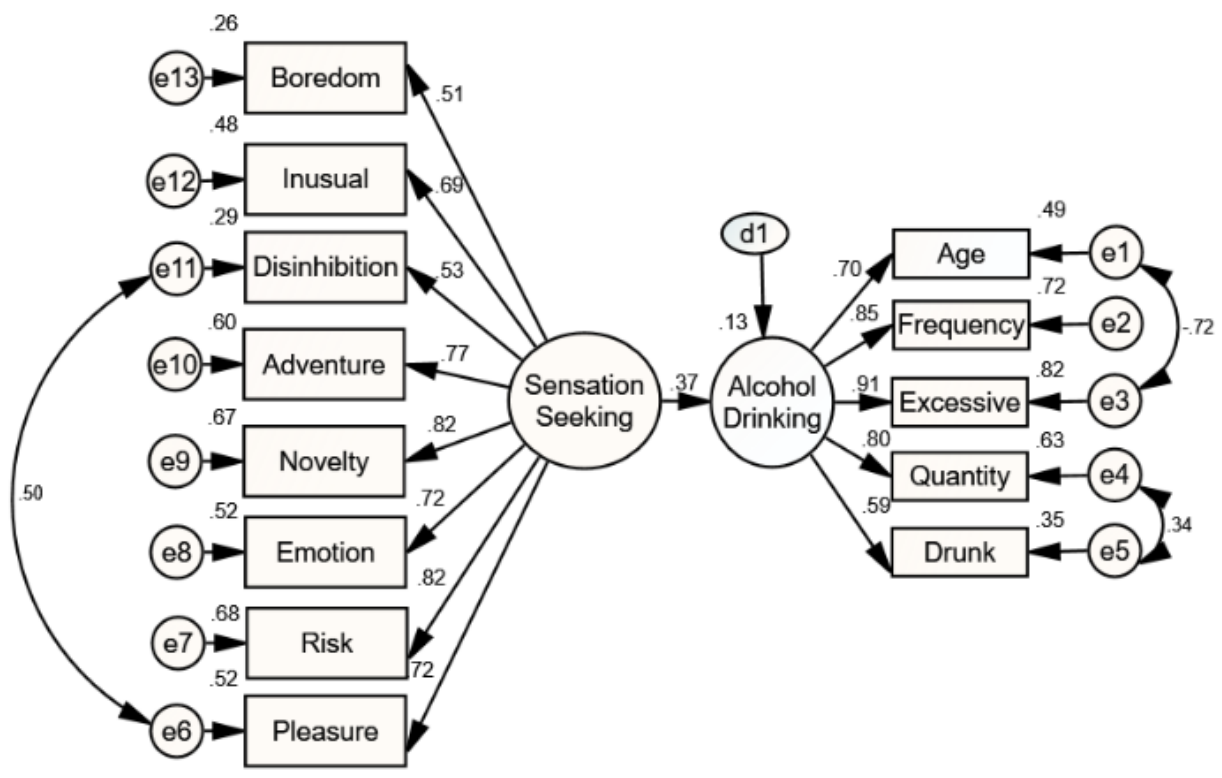

Figure 1. Structural equation model of sensation seeking and incidence of alcohol consumption

Results from our data results are congruent with the hypothesis, indicating that sensation seeking is a precursor to consuming alcohol, so that structural equations are a useful explanation of this behavior. Furthermore, it provides theoretical evidence of sensation seeking (Hit- tner \& Swickert, 2006; Palacios, 2015a; Roberti, 2004; Zuckerman, 1994, 2007) in the prediction of the behavior of alcohol consumption in Mexico. The data indicated that increased sensation seeking is associated with high levels of alcohol consumption. 
The contribution of this study was to obtain the factorial validity of alcohol consumption in Mexican adolescents. The second contribution was to empirically estimate the model proposed to discover the direction and magnitude of the influence of sensation seeking on alcohol consumption, in a valid, reliable and culturally sensitive way. Sensation seeking is linked to the need for stimulation; so that the consumption of alcohol is the result of curiosity, experimentation and trying new activities (Palacios, 2015a; Zuckerman, 1994, 2007; Zuckerman \& Kuhlman, 2000); that is, the adolescents of this study are sensation seekers, influenced by emotion to experience novel sensations (Palacios, 2015a; Palacios \& Cañas, 2010; Zuckerman, 1994, 2007) that induce them to consume alcohol in various quantities. The facets of sensation seeking find broad support in the sensation seeking personality traits (Hittner \& Swickert, 2006; Palacios, 2015a; Palacios et al., 2010; Roberti, 2004; Zuckerman, 1994, 2007), as well as in studies (Breivik et al., 2017; Cooper et al., 2003; Legrand et al., 2007; Merino-Soto \& Salas-Blas, 2018; Romero Saletti et al., 2017; Yanovitzky, 2006) that have identified sensation seeking as one of the reasons for the initiation of alcohol consumption among adolescents. Several limitations in the present study should be noted. First the sample is limited to Mexico City, so these results can not be generalized to the entire adolescent population, but reflect what is happening with a sample of Mexican youth. Second, the measures used here relied on self reports which were not corroborated by a known outside measure, although there is some evidence that self reports on alcohol use yield valid and reliable measures in most instances. Third, measures of alcohol drinking relied on adolescent self reports; it is possible that adolescents under- or over-reported their alcohol behaviors. However, youth responses surveys in this sample were compared with the results of national surveys. Fourth, other risky behaviors and psychological constructs of the nomological network can be used to obtain evidence of convergent and discriminant validity of the Mexican sensation-seeking scale. Finally, this study doesn't permit causal inferences regarding the relationship between sensation seeking and alcohol drinking. Of particular concern in this respect is the actual causal direction between sensation seeking and alcohol drinking, because the study did not include other variables that are involved in alcohol consumption. Causal direction involves in part the establishment of temporal precedence between variables;causal direction in some instances, may be the reverse of the hypothesized relationship. For example, the consumption of alcohol could lead youth to lose their inhibitions or be more friendly among peers (Palacios, 2012).

The present study has theoretical and practical implications. Theoretically, the study demonstrates the importance of researching sensation seeking from a biobehav- ioral perspective (Roberti, 2004; Zuckerman, 1994, 2007) as a personality trait to show a positive and signicant direct influence between sensation seeking and alcohol drinking. For this perspective, it has been shown that sensation seeking is part of specific behavioral patterns in which biological predisposition (Brocke, Beauducel, \& Tasche, 1999; Roberti, 2004; Zuckerman, 1990, 1994, 2007) interacts with social environment (Arnett, 1994), so that sensation seeking is characterized as a biosocial personality trait (Zuckerman, 1994, 2007).

These results confirm previous research and expand our understanding of the dynamics of individual factors (personality factors) influencing alcohol drinking in adolescents. Consequently, they have implications for the evaluation and development of prevention programs for Mexican youth. Intervention approaches may need to vary among youth who have high propensities towards sensation seeking. For instance, an intensive mass media campaign using public service announcements was shown to be effective in changing behaviors among youth with high levels of sensation seeking (Palacios \& Bustos, 2012). Based on results of the current study, a mass media approach can be strengthened if combined with interventions that seek to limit opportunities for high sensation seekers to interact with alcohol users or create more opportunities for high sensation seekers to interact with peers who abstain from alcohol use or drink responsibly (Yanovitzky, 2006). These proposals will continue to guide future research on effective interventions in college drinking.

In conclusion, identifying and predicting high levels of sensation seeking in adolescents is an important element to consider in the field of prevention, because sensation seeking has been identified as a risk factor in the consumption of addictive substances. If we can understand how the need for external sensorial stimulation is involved in the search for risk, we can understand that those who seek sensations are characterized by actions that are dangerous and risky for others, personality characteristics present in alcohol consumption in Mexican youth.

\section{References}

Arnett, J. (1994). Sensation seeking: A new conceptualization and a new scale. Personality and Individual Differences, 16, 289-289.

Bandura, A. (1999). A sociocognitive analysis of substance abuse: An agentic perspective. Psychological Science, 10(3), 214-217.

Becoña, E. (2005). Bases científicas de la prevención de las drogodependencias. Madrid: Plan Nacional sobre Drogas.

Breivik, G., Sand, T. S., \& Sookermany, A. M. (2017). Sensation seeking and risk-taking in the Norwegian 
population. Personality and Individual Differences, 119, 266-272.

Brocke, B., Beauducel, A., \& Tasche, K. G. (1999). Biopsychological bases and behavioral correlates of sensation seeking: Contributions to a multilevel validation. Personality and Individual Differences, 26(6), 1103-1123.

Chen, X., Li, F., Nydegger, L., Gong, J., Ren, Y., DinajKoci, V., ... Stanton, B. (2013). Brief sensation seeking scale for chinese-cultural adaptation and psychometric assessment. Personality and Individual Differences, 54(5), 604-609.

Church, A. T. (2001). Personality measurement in crosscultural perspective. Journal of Personality, 69(6), 979-1006.

Cooper, M. L. (1994). Motivations for alcohol use among adolescents: Development and validation of a four-factor model. Psychological Assessment, $6(2), 117-128$.

Cooper, M. L., Agocha, V. B., \& Sheldon, M. S. (2000). A motivational perspective on risky behaviors: The role of personality and affect regulatory processes. Journal of Personality, 68(6), 1059-1088.

Cooper, M. L., Wood, P. K., Orcutt, H. K., \& Albino, A. (2003). Personality and the predisposition to engage in risky or problem behaviors during adolescence. Journal of Personality and Social Psychology, 84(2), 390-410.

Crawford, A. M., Pentz, M. A., Chou, C.-P., Li, C., \& Dwyer, J. H. (2003). Parallel developmental trajectories of sensation seeking and regular substance use in adolescents. Psychology of Addictive Behaviors, 17(3), 179-192.

Encuesta Nacional de Adicciones. (2011). Alcohol. Secretaria de Salud, Consejo Nacional contra las Adicciones, Comisión Nacional contra las Adicciones, Instituto Nacional de Psiquiatría, Instituto Nacional de Salud Pública.

Goldberg, L. R. (1990). An alternative" description of personality": the big-five factor structure. Journal of Personality and social Psychology, 59(6), 1216-1229.

Gómez Fraguela, J. A., Luengo Martín, A., Romero Triñanes, E., Villar Torres, P., \& Sobral Fernández, J. (2006). Estrategias de afrontamiento en el inicio de la adolescencia y su relación con el consumo de drogas y la conducta problemática. International Journal of Clinical and Health Psychology, 6(3), 581-597.

González-Iglesias, B., Gómez-Fraguela, J.-A., Gras, M.E., \& Planes, M. (2014). Búsqueda de sensaciones y consumo de alcohol: el papel mediador de la percepción de riesgos y beneficios. Anales de Psicología, 30(3), 1061-1068.

Grant, V. V., Stewart, S. H., O'Connor, R. M., Black- well, E., \& Conrod, P. J. (2007). Psychometric evaluation of the five-factor Modified Drinking Motives Questionnaire-Revised in undergraduates. Addictive Behaviors, 32(11), 2611-2632.

Hansen, E. B., \& Breivik, G. (2001). Sensation seeking as a predictor of positive and negative risk behaviour among adolescents. Personality and Individual Differences, 30(4), 627-640.

Hawkins, J. D., Catalano, R. F., \& Miller, J. Y. (1992). Risk and protective factors for alcohol and other drug problems in adolescence and early adulthood: implications for substance abuse prevention. Psychological Bulletin, 112(1), 64-105.

Hittner, J. B., \& Swickert, R. (2006). Sensation seeking and alcohol use: A meta-analytic review. Addictive Behaviors, 31(8), 1383-1401.

Horvath, P., \& Zuckerman, M. (1993). Sensation seeking, risk appraisal, and risky behavior. Personality and Individual Differences, 14(1), 41-52.

Jessor, R. (1991). Risk behavior in adolescence: a psychosocial framework for understanding and action. Journal of Adolescent Health, 12, 597-605.

Jessor, R. (1998). New perspectives on adolescent risk behavior. In (pp. 1-10). Cambridge University Press.

Kandel, D. B. (2002). Stages and pathways of drug involvement: Examining the gateway hypothesis. Cambridge University Press.

Legrand, F. D., Kaltenbach, M. L., Joly, P. M., et al. (2007). Association between sensation seeking and alcohol consumption in French college students: Some ecological data collected in "open bar" parties. Personality and Individual Differences, 43(7), 1950-1959.

McCrae, R. R. (2001). Trait psychology and culture: Exploring intercultural comparisons. Journal of Personality, 69(6), 819-846.

Medina-Mora, M., Natera, G., \& Borges, G. (2002). Alcoholismo y abuso de bebidas alcohólicas. Observatorio Mexicano en tabaco, alcohol y otras drogas. México, DF: Secretaría de Salud. Retrieved from www.conadic.gob.mx/investigacion/ observatorio_2002/observatorio_1.pdf

Medina Mora, M. A., Peña Corona, M. P., Cravioto, P., Villatoro, J., Kuri, P., et al. (2002). Del tabaco al uso de otras drogas: ¿el uso temprano de tabaco aumenta la probabilidad de usar otras drogas? Salud Pública de México, 44(supl 1), s109-s115.

Merino-Soto, C., \& Salas-Blas, E. (2018). Brief Sensation Seeking Scale: Latent structure of 8-item and 4item versions in Peruvian adolescents Escala breve de búsqueda de sensaciones (BSSS): estructura latente de las versiones de 8 y 4 ítems en adolescentes peruanos. Adicciones, 30(1), 41-53.

Newcomb, M. D., \& Bentler, P. M. (1989). Substance use 
and abuse among children and teenagers. American Psychology, 44(2), 242-248.

Palacios, D. J. (2011). Las conductas de riesgo del adolescente. México: Centro de Investigación Biopsicosocial, AC.

Palacios, D. J. (2012). Exploración de los motivos para consumir alcohol en adolescentes. Psicología Iberoamericana, 20(1), 29-39.

Palacios, D. J. (2015a). Propiedades psicométricas del inventario de búsqueda de sensaciones para adolescentes en México (IBS-Mx). International Journal of Psychological Research, 8(1), 46-60.

Palacios, D. J. (2015b). Estimación psicométrica de la escala de autoeficacia ante conductas de riesgo para adolescentes en México. Psychosocial Intervention, $24(1), 1-7$.

Palacios, D. J., Bravo, F. M., \& Andrade, P. P. (2007). Consumo de alcohol y conducta sexual de riesgo en adolescentes. Psychology International, 18(4), $1-13$.

Palacios, D. J., \& Bustos, A. J. M. (2012). La teoría como promotor para el desarrollo de intervenciones psicoambientales the role of theory in developing psycho-environmental interventions. Psychosocial Intervention, 21(3), 245-257.

Palacios, D. J., \& Cañas, M. J. (2010). Características psicosociales asociadas al consumo de alcohol, tabaco y drogas en adolescentes de chiapas. Revista Psicología Iberoamericana, 18(2), 27-36.

Palacios, D. J., \& Martínez, R. (2017). Descripción de características de personalidad y dimensiones socioculturales en jóvenes mexicanos. Revista de Psicología, 35(2), 453-484.

Palacios, D. J., Sánchez, T. B., \& Andrade. (2010). Intento de suicidio y búsqueda de sensaciones en adolescentes. Revista Intercontinental de Psicología y Educación, 12(1), 53-75.

Perkins, K., Gerlach, D., Broge, M., Grobe, J., \& Wilson, A. (2000). Greater sensitivity to subjective effects of nicotine in nonsmokers high in sensation seeking. Experimental and Clinical Psychopharmacology, 8, 462-471.

Roberti, J. W. (2004). A review of behavioral and biological correlates of sensation seeking. Journal of Research in Personality, 38(3), 256-279.

Romero Saletti, S., Olivo Chang, D., Pérez-Aranibar, C. C., \& Otiniano Campos, F. (2017). Psychometric properties of the Brief Sensation Seeking Scale in peruvian teenagers. Psicothema, 29(1), 133-138.

Roth, M., Hammelstein, P., \& Brähler, E. (2007). Beyond a youthful behavior style-Age and sex differences in sensation seeking based on need theory. Personality and Individual Differences, 43(7), 1839-1850.

Ruiz, M. A., Pardo, A., \& San Martín, R. (2010). Mode- los de ecuaciones estructurales. Papeles del Psicólogo, 31(1).

Saletti, S. R., Chang, D. O., Pérez-Aranibar, C. C., \& Campos, F. O. (2017). Propiedades psicométricas de la Brief Sensation Seeking Scale en adolescentes peruanos. Psicothema, 29(1), 133-138.

Salud. (2011). Reglamento de la Ley General de Salud en Materia de Investigación para la Salud. Retrieved from www.salud.gob.mx/unidades/cdi/ nom/compi/rlgsmis.html

Schmidt, V., Molina, M. F., \& Raimundi, M. J. (2017). The Sensation Seeking Scale (SSS-V) and its use in Latin American Adolescents: Alcohol consumption pattern as an external criterion for its validation. Europe's Journal of Psychology, 13(4), 776.

Smorti, M., \& Guarnieri, S. (2013). A study on the validity of the Arnett Inventory of Sensation Seeking (AISS) in an adolescent Italian sample. International Journal of Advances in Psychology, 2(1), 10-18.

Stephenson, M. T., Hoyle, R. H., Palmgreen, P., \& Slater, M. D. (2003). Brief measures of sensation seeking for screening and large-scale surveys. Drug and Alcohol Dependence, 72(3), 279-286.

Stephenson, M. T., Velez, L. F., Chalela, P., Ramirez, A., \& Hoyle, R. H. (2007). The reliability and validity of the Brief Sensation Seeking Scale (BSSS-8) with young adult Latino workers: Implications for tobacco and alcohol disparity research. Addiction, 102, 79-91.

Villatoro, J., Medina-Mora, M. E., Rojano, C., Fleiz, C., Villa, G., Jasso, A., ... Blanco, J. (2001). Consumo de Drogas, Alcohol y Tabaco en Estudiantes del Distrito Federal: Medición otoño 2000. Reporte global INP - SEP. México.

Yanovitzky, I. (2006). Sensation seeking and alcohol use by college students: Examining multiple pathways of effects. Journal of Health Communication, 11(3), 269-280.

Zuckerman, M. (1979). Sensation seeking: Beyond the optimal level of arousal. Erlbaum Associates Hillsdale, NJ.

Zuckerman, M. (1990). The psychophysiology of sensation seeking. Journal of Personality, 58(1), 313-345.

Zuckerman, M. (1994). Behavioral expressions and biosocial bases of sensation seeking. Cambridge university press.

Zuckerman, M. (2007). Sensation seeking and risky behavior. Washington: American Psychological Association.

Zuckerman, M., \& Kuhlman, D. M. (2000). Personality and risk-taking: common bisocial factors. Journal of Personality, 68(6), 999-1029. 